\title{
Evidence of sex reversal in the gonads of chicken embryos after oestrogen treatment as detected by expression of lutropin receptor
}

\author{
Y. Akazome and T. Mori \\ Department of Biological Sciences, Graduate School of Science, University of Tokyo, Bunkyo-ku, Tokyo 113-0033, Japan
}

\begin{abstract}
In chicken embryos, there is a difference between the sexes in the onset of lutropin receptor mRNA expression in the gonads. The effects of oestrogen on lutropin receptor expression were studied to investigate the mechanism controlling this difference. Lutropin receptor mRNA expression was detected in the ovaries of sesame oil-treated control female embryos on day 12 of incubation, while no expression was found in the testes of the male controls. Oestradiol administration to genetically male embryos before sexual differentiation resulted in gonadal sex reversal which was characterized histologically by the proliferation of cortical cords and the presence of lacunae. Lutropin receptor expression was detected in the feminizing testis on day 12 of incubation. Administration of aromatase inhibitor (CGS 16949 A) to genetically female embryos before sexual differentiation inhibited the formation of cortical cords, although a relatively weak expression of lutropin receptor was detected. These results indicate that early expression of the lutropin receptor is regulated by oestrogen.
\end{abstract}

\section{Introduction}

In chicken embryos, the gonadal activity of steroidogenesis differs between the testis and ovary. Ovarian oestrogen production increases markedly from day 8 of incubation, while testicular androgen production increases gradually during the latter half of incubation (Tanabe et al., 1986). The organization of accessory sex organs is determined by these gonadal sex steroids. In avian species with female heterozygosity ( $\mathrm{ZZ/ZW}$ sex determination), the basic morphology of the sex accessories is the male type. Therefore, the timely secretion of oestrogen is necessary for the acquisition of female characteristics. Lutropin secreted from the pituitary gland is the major hormone that stimulates gonadal oestrogen synthesis and secretion. In chicken embryos, circulating lutropin can be detected from day 8 of incubation (Tanabe et al., 1986). Equine lutropin administration promotes both ovarian and testicular steroidogenesis from day 7.5, suggesting that lutropin is important in embryonic steroidogenesis (Woods et al., 1981). In chickens, lutropin receptor mRNA appears on day 7 of incubation in the ovary and on day 14 in the testis (Akazome et al., 1997), as determined by in situ hybridization using a cRNA probe.

When rudimentary gonads appear on the surface of the mesonephros, they have the potential to differentiate into ovaries or testes. In chicken embryos, rudimentary gonads appear on day 4 to day 5 of incubation. The ovary and testis can be distinguished histologically on day 6 to day 7 of incubation: the surface epithelium of the left ovary develops into cortical cords (secondary sex cords) and lacunae are formed in the medulla by the distension of medullary cords (primary sex cords) (Romanoff, 1960). Oestrogen has long been considered a factor in the determination of gonadal sex in some non-mammalian species. Elbrecht and Smith (1992) demonstrated that administration of aromatase inhibitor before sexual differentiation results in complete sex reversal in genetically female chicken embryos. This was the first report of sex reversal in amniotes.

The aim of this study was to clarify the role of oestrogen in the developing gonads of chickens by examining the effects of oestradiol and aromatase inibitor on lutropin receptor expression.

\section{Materials and Methods}

\section{Animals}

Fertilized White Leghorn eggs were obtained from a commercial source and incubated at $37.6-37.7^{\circ} \mathrm{C}$ with $58-69 \%$ humidity.

\section{Chemical treatments}

Treatments were administered into the air sac of the eggs with a syringe. Before injection, small holes were made on the blunt ends of the eggs. The holes were closed with sterilized paraffin wax after injection. On day 3 or 5 of incubation, $0.1 \mathrm{mg}$ of oestradiol solubilized in $0.1 \mathrm{ml}$ sesame oil containing $10 \%$ ethanol was injected into the eggs selected for oestradiol treatment. A group of control eggs was injected with $0.1 \mathrm{ml}$ sesame oil with $10 \%$ ethanol (control). In the aromatase inhibitor experiment, on day 5 of incubation, embryos were 
injected with 0.2 or $1.0 \mathrm{mg}$ aromatase inhibitor (CGS 16949 A; Ciba-Geigy Co., Summit, NJ) solubilized in $0.2-1.0 \mathrm{ml}$ saline. Aromatase inhibitor is known to block the conversion of androgen to oestrogen. Control eggs in this experiment were injected with $0.2 \mathrm{ml}$ saline. In the inhibitor experiment, only the genetically female embryos were examined. Both the dose and time of treatments were according to the reports of Narbaitz and De Robertis (1970) and Abinawanto et al. (1996).

\section{In situ hybridization}

On day 12 of incubation, embryos were fixed overnight in $\mathrm{Ca}^{2+}$ - and $\mathrm{Mg}^{2+}$-free Dulbecco's PBS containing 4\% (w/v) paraformaldehyde. The fixed embryos were dehydrated through an ethanol series, embedded in paraplast and cut into $5 \mu \mathrm{m}$ sections. The sections were rehydrated, treated with Triton-X100 and then immersed in $0.2 \mathrm{~mol} \mathrm{HCl}^{-1}$. The sections were digested with proteinase $\mathrm{K}$, dehydrated, and dried before hybridization. The $\left.{ }^{35} \mathrm{~S}\right]$ lutropin receptor cRNA probe was generated as described by Akazome et al. (1997). Hybridization was carried out in hybridization solution $(50 \%$

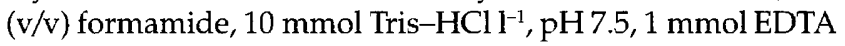

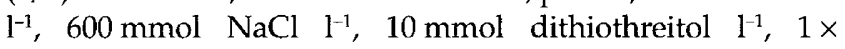
Denhardt's reagent, $0.25 \%(\mathrm{w} / \mathrm{v}) \mathrm{SDS}, 10 \%(\mathrm{w} / \mathrm{v})$ polyethylene glycol 6000 , and $200 \mu \mathrm{g}$ yeast tRNA ml-1) containing $1.5 \times 10^{4}$ counts per $\min$ (c.p.m.) per microlitre probe. The tissue sections were covered with parafilm (American National Can, Greenwich, CT) and incubated overnight at $50^{\circ} \mathrm{C}$. After hybridization, the sections were washed in a solution of $2 \times \mathrm{SSC}\left(150 \mathrm{mmol} \mathrm{NaCl}^{-1}, 15 \mathrm{mmol}\right.$ trisodium citrate $\mathrm{l}^{-1}, \mathrm{pH}$ 7.0) containing $50 \%(\mathrm{v} / \mathrm{v})$ formamide, and digested with $10 \mu \mathrm{g}$ ribonuclease A (RnaseA; Sigma, St Louis, MO) $\mathrm{ml}^{-1}$ at $37^{\circ} \mathrm{C}$ for $30 \mathrm{~min}$ to remove non-hybridized probes. The sections were washed twice with $2 \times$ SSC at $42^{\circ} \mathrm{C}$ for $15 \mathrm{~min}$ and twice with $0.5 \times \mathrm{SSC}$ at $42^{\circ} \mathrm{C}$ for $15 \mathrm{~min}$, and were then dehydrated in an ethanol series containing $0.3 \mathrm{~mol}$ ammonium acetate $1^{-1}$ ( $\mathrm{pH}$ 5.2). The slides were coated with autoradiographic emulsion (NR-M2; Konica Medical, Tokyo). The exposure was performed at $4^{\circ} \mathrm{C}$ in a light-tight box for 1 week. After developing, the sections were counterstained with Mayer's haematoxylin.

\section{Sexing of embryos}

The genetic sex of the embryos was determined according to the presence of chromodomain-helicase-DNA-binding protein W-linked (CHD-W) and related autosomal genes (CHD-NW). Genomic DNA was extracted from liver tissue that had been homogenized in DNA extraction buffer (50 mmol Tris- $\mathrm{HCl} \mathrm{l}^{-1}, \mathrm{pH} \mathrm{8.0,50} \mathrm{mmol} \mathrm{EDTA}{ }^{-1}, 2 \%(\mathrm{w} / \mathrm{v})$ SDS) containing $10 \mu \mathrm{g}$ RNase $\mathrm{A} \mathrm{ml}^{-1}$. The tissue suspension was digested with proteinase $\mathrm{K}$ at $50^{\circ} \mathrm{C}$ for $3 \mathrm{~h}$, and extracted twice with phenol. The DNA was collected from the aquatic fraction by ethanol precipitation. DNA fragments of CHD-W and CHD-NW genes were amplified by PCR using a set of primers as described by Griffiths et al. (1996).

\section{Results}

\section{Oestrogen-treated embryos}

In the sesame oil-treated control group, the histological classification of sex in 12 day embryos was consistent with the results of sex determination by genomic analysis (Table 1). In this group, the gonads of male embryos possessed a single-layered surface epithelium and well-developed testicular cords (Fig. 1a) in which no lutropin receptor mRNA expression was visible (Fig. 1b). In the left ovaries of sesame oil-treated embryos, cortical cords had proliferated. The medullary cords in the outer medullary zone underneath the surface epithelium were massive, and lacunae were localized in the inner medullary zone (Fig. 1e). Lutropin receptor mRNA signals were detected in the medulla (Fig. 1f). The right ovaries, which were smaller than the left ovaries, failed to develop the cortices but exhibited mRNA signals in the medulla (data not shown). These findings are consistent with previous results from intact ovaries of day 12 embryos (Akazome et al., 1997).

Oestradiol administration to genetically male embryos resulted in proliferation of the cortices and formation of lacunae in the left gonad, the structure of which was similar to that in the left ovary of genetically female embryos (Fig. $1 c, e)$. In these feminizing gonads, lutropin receptor mRNA expression was visible in the medulla (Fig. 1d), although it was considered to be weaker than that in the sesame oiltreated genetic females (Fig. 1f). The presence of some mRNA for lutropin receptor in the right gonads of oestradiol-treated genetic males was the same as observed in the right gonads of sesame oil-treated females (data not shown). In genetically female embryos treated with oestradiol, the gonads showed no difference from those in the sesame oil-treated female embryos, both in histological characteristics and lutropin receptor mRNA expression (data not shown).

Table 1. Relationship of genetic sex determination with histological and lutropin receptor mRNA expression characteristics in sesame oil-treated 12-day-old chicken embryos

\begin{tabular}{lccc}
\hline Number of embryos & Genetic sex & $\begin{array}{c}\text { Number of embryos with } \\
\text { cortical cords }\end{array}$ & $\begin{array}{c}\text { Number of embryos with } \\
\text { lutropin receptor expression }\end{array}$ \\
\hline 6 & Male & 0 & 0 \\
4 & Female & 4 & 4 \\
\hline
\end{tabular}

For observations of the cortical cords, only the left gonads were considered, while for lutropin receptor mRNA expression, both right and left gonads were analysed. 

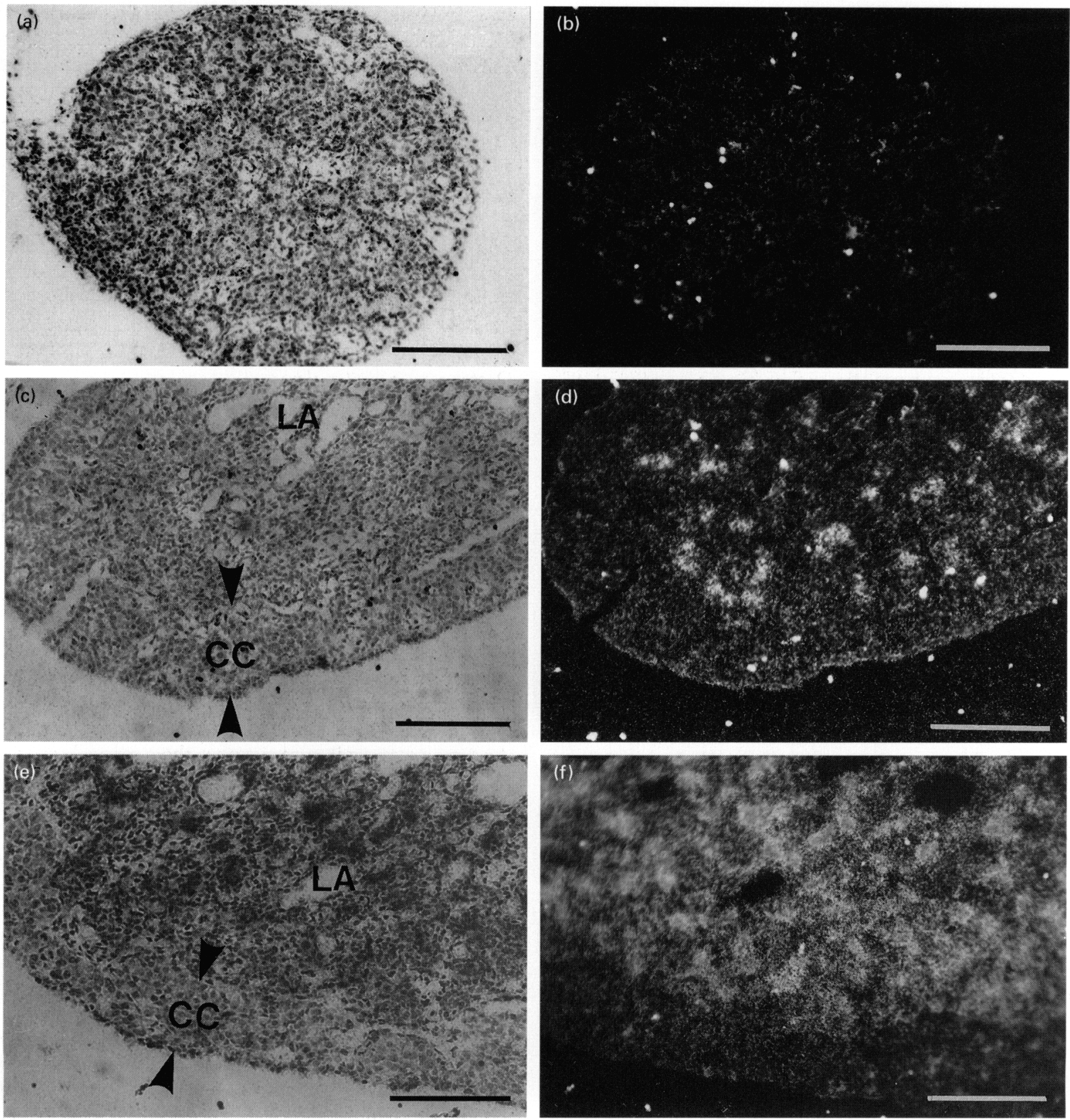

Fig. 1. Effects of oestradiol treatment on the gonads of chicken embryos. Bright-field $(a, c, e)$ and dark-field $(b, d, f)$ photomicrographs of sections of the left gonads of embryos treated with oestradiol or sesame oil (control). (a,b) Genetically male embryo treated with sesame oil. $(c, d)$ Genetically male embryo treated with oestradiol. (e,f) Genetically female embryo treated with sesame oil. (b), (d) and (f) show hybridization signals with the lutropin receptor antisense-strand RNA probe. These are the same fields as (a), (c) and (e), respectively. CC, cortical cord; LA, lacuna. Scale bars represent $100 \mu \mathrm{m}$

\section{Aromatase inhibitor-treated embryos}

In genetically female embryos treated with saline, the left gonads were as well developed as the left ovaries in the sesame oil-treated group (Fig. 2a,b). The right gonads were markedly reduced in size (Fig. 2a). Lutropin receptor mRNA expression was detected in the medullary cords of both ovaries (Fig. 2c), as reported in the ovaries of intact 12 day embryos (Akazome et al., 1997).
In the genetically female embryos, the development of cortical cords in the left gonads was retarded after aromatase inhibitor treatment (Fig. 2d), and the lacunae extended underneath the surface epithelium as reported by Wartenberg et al. (1992) (Fig. 2e). Therefore, the tissue of the left gronads in the aromatase inhibitor group was composed of loosely arranged cells. The right gonads of the aromatase inhibitor-treated embryos contained more densely arranged cells than those in saline-treated embryos. Thus, both the 

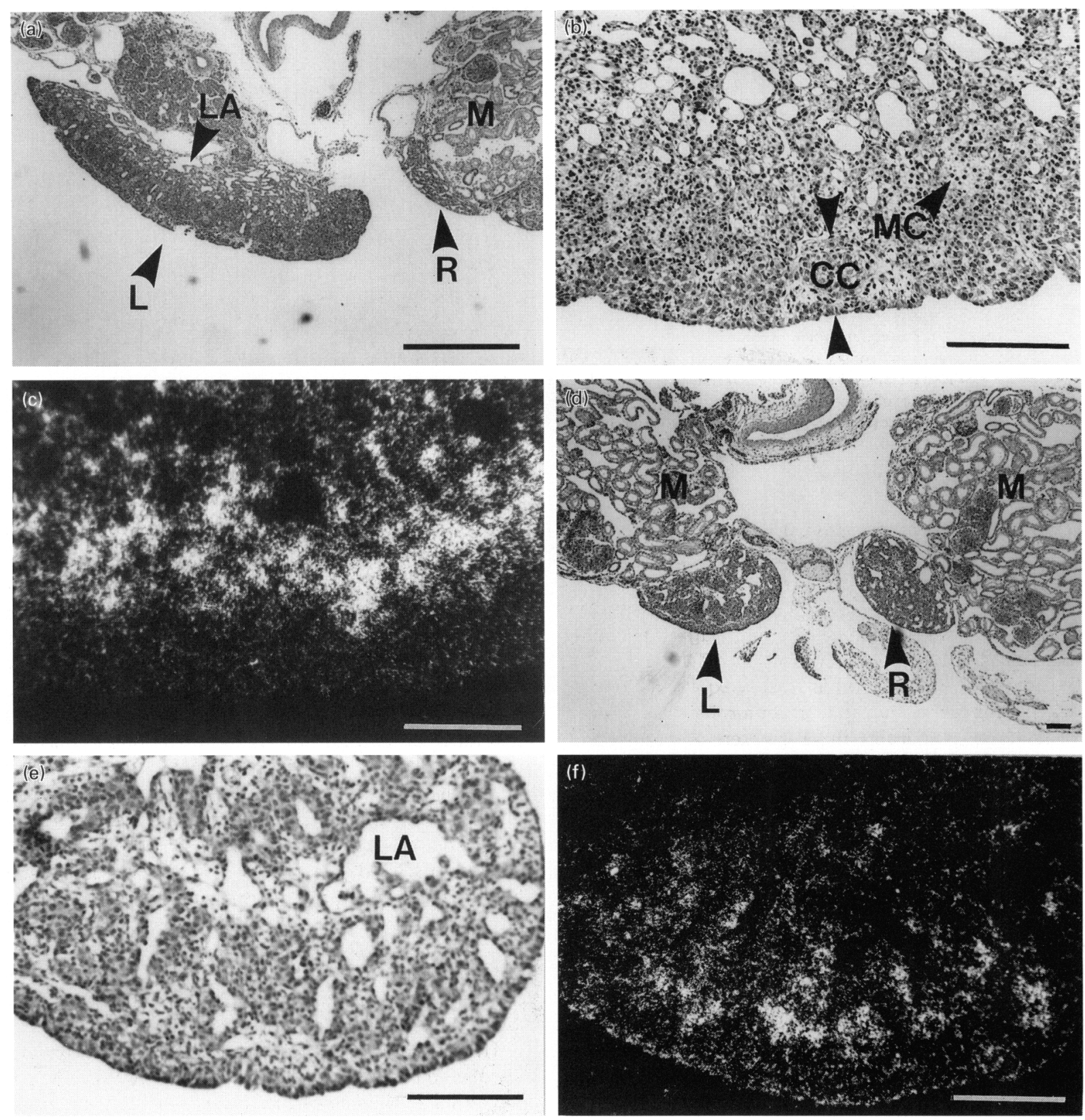

Fig. 2. Effects of aromatase inhibitor treatment on the gonads of chicken embryos. (a) Cross-section of paired gonads from a saline-treated (control) genetically female embryo. (b) Magnified section of (a). (c) Dark-field photomicrograph of section adjacent to (b) hybridized with the lutropin receptor antisense-strand RNA probe. (d) Cross-section of paired gonads from an aromatase inhibitor-treated genetically female embryo. (e) Magnified section of (d). (f) Dark-field photomicrograph of section adjacent to (e) hybridized with the lutropin receptor antisensestrand RNA probe. The sections are stained with haematoxylin and eosin. Lacunae are localized towards the inner part of the medulla. In the aromatase inhibitor-treated gonads, the development of the cortical cords is prevented and the lacunae extend underneath the surface epithelium. In these gonads, the silver grains are sparsely distributed (see (f)) compared with those in the saline-treated ovaries (see (c)). CC, cortical cord; L, left gonad; LA, lacuna; M, mesonephros; MC, medullary cord; R, right gonad. Scale bars represent $100 \mu \mathrm{m}$.

right and left gonads in the aromatase inhibitor group appeared symmetrical (Fig. 2d) and they had weak lutropin receptor mRNA signals compared with those in the salinetreated female embryos (Fig. 2c,f).

The results of oestradiol and aromatase inhibitor treatments are summarized (Table 2 ).

\section{Discussion}

In rats, full-length lutropin receptor mRNA is expressed from day 15.5 in the embryonic testis (Zhang et al., 1994), and from day 7 after birth in the ovary (Sokka et al., 1992). Early expression of lutropin receptor in male rats is related to the 
Table 2. Effects of oestradiol and aromatase inhibitor on lutropin receptor mRNA expression in the gonads of chicken embryos

\begin{tabular}{|c|c|c|c|}
\hline Treatments & Genetic sex & Cortical cords & Lutropin receptor $\mathrm{mRNA}$ \\
\hline Sesame oil & Male & $0 / 6$ & $0 / 6$ \\
\hline Oestradiol $\times 1$ ( $0.1 \mathrm{mg}$ on day 3 of incubation $)$ & Male & $3 / 3$ & $3 / 3$ \\
\hline Oestradiol $\times 2(0.1 \mathrm{mg}$ on days 3 and 5 of incubation $)$ & Male & $2 / 2$ & $2 / 2$ \\
\hline Saline & Female & $4 / 4$ & $4 / 4$ \\
\hline Aromatase inhibitor ( $0.2 \mathrm{mg}$ on day 5 of incubation) & Female & $0 / 6$ & $6 / 6$ \\
\hline Aromatase inhibitor ( $1.0 \mathrm{mg}$ on day 5 of incubation) & Female & $0 / 2$ & $2 / 2$ \\
\hline \multicolumn{4}{|c|}{$\begin{array}{l}\text { For observations of the cortical cords, only the left gonads were considered, and for lutropin receptor mRNA expression, both right } \\
\text { and left gonads were analysed. } \\
\text { Sesame oil was the control for the oestradiol treatment and saline was the control for the aromatase inhibitor treatment. } \\
\text { Results from female embryos treated with sesame oil }(n=4) \text {, oestradiol } \times 1(n=7) \text { and oestradiol } \times 2(n=6) \text { are not shown as there } \\
\text { was no evidence of sex reversal in these groups. } \\
\text { Data are presented as number of samples with cortical cords or lutropin receptor mRNA signals relative to the total number of } \\
\text { samples examined. }\end{array}$} \\
\hline
\end{tabular}

high secretory activity of androgen in young mammalian males. Early lutropin receptor expression may be important for masculinization in mammalian species with male heterozygosity. In contrast, in chicken embryos, lutropin receptor mRNA appears from day 7 of incubation in females and from day 14 in males (Akazome et al., 1997).

In the present study, the mechanism of sexual dimorphism in chicken embryonic lutropin receptor expression was investigated. In genetically male chicken embryos, both oestradiol and diethylstilboestrol treatments before sexual determination induce sex reversal as characterized by the proliferation of the cortex in the left gonad (Willier et al., 1935; Wolff and Ginlinger, 1935; Perrin et al., 1995). Elbrecht and Smith (1992) reported that aromatase inhibitor treatment before sexual differentiation brought about sex reversal of genetic females. These findings indicate the significance of oestrogen in sex determination. In the present study, treatment of genetically male gonads with oestradiol enhanced lutropin receptor mRNA expression and treatment of genetically female gonads with aromatase inhibitor decreased expression. In addition, these treatments induced sex reversal in the histological characteristics of the gonads. Therefore, oestrogen plays a key role in female-specific early lutropin receptor expression and histological feminization in the gonads of chicken embryos. This raises the question as to whether the appearance of gonadal oestradiol is due to lutropin stimulation in the chicken embryo. In hypophysectomized chicken embryos, the ovary secretes oestradiol up to days 16-18 of incubation (Weniger and Zeis, 1987; Weniger et al., 1989). Furthermore, the number of lutropin binding sites in the ovaries of hypophysectomized chicken embryos is not different from that in intact embryos (Woods et al., 1989). Gasc (1980) reported that tritiumlabelled oestradiol binds to sites in the medullary cord and surface epithelium of the left gonads before sexual differentiation in chicken embryos. The cDNA sequence of the chicken oestrogen receptor has been determined (Krust et al., 1986; Maxwell et al., 1987). In chickens, oestrogen receptor mRNA was detected in the embryonic testis as well as in the ovary by reverse transcription-PCR from day 4.5 (Smith et al., 1997) or from day 7 (Nakabayashi et al., 1997). These findings indicate that initiation of oestrogen secretion and oestrogen receptor expression is automatic. Therefore, it is speculated that endogenous oestrogen induces lutropin receptor mRNA expression in the ovary. In rats, oestradiol promotes lutropin receptor expression as a result of granulosa cell proliferation in the ovarian follicle (Richards et al., 1976; Knecht et al., 1984, 1985a,b). However, it is possible that lutropin receptor mRNA is expressed at a concentration below that detectable by in situ hybridization before day 7 .

Thecal cells that express lutropin receptor in young follicles are thought to originate from fibroblast-like precursor cells (Erickson et al., 1985) or cortical cord cells (Byskov et al., 1985). However, in both intact and oestradioltreated embryonic gonads, lutropin receptor expression was localized in the medulla. The medullary cords are present in the mature ovary, but they lose the primordial germ cells during ovarian maturation (Romanoff, 1960). Therefore, the cell population containing lutropin receptor mRNA may be different between embryonic and adult ovaries.

The mechanism of testicular lutropin receptor expression remains to be elucidated. The concentration of oestrone and oestradiol in the chicken testis are much lower than in the ovary (Woods and Erton, 1978; Tanabe et al., 1986; Yoshida et al., 1996), which may be responsible for the delay in expression of lutropin receptor.

The authors thank M. K. Park in their laboratory for his helpful discussions. This work was supported by grants from JSPS Research Fellowships for Young Scientists (Y. Akazome) and a Grant-in-Aid for Scientific Research from the Ministry of Education, Science, Sports and Culture of Japan (T. Mori).

\section{References}

Abinawanto, Shimada K, Yoshida K and Saito N (1996) Effects of aromatase inhibitor on sex differentiation and levels of P45017a and P450arom messenger ribonucleic acid of gonads in chicken embryos General and Comparative Endocrinology 102 241-246

Akazome Y, Yasugi S, Park MK and Mori T (1997) Ontogeny of the 
expression of messenger ribonucleic acid encoding lutropin receptor in chicken embryo Zoological Science 14 363-367

Byskov AG, Hoyer PE and Westergraard L (1985) Origin and differentiation of the endocrine cells of the ovary Journal of Reproduction and Fertility 75 299-306

Elbrecht A and Smith RG (1992) Aromatase enzyme activity and sex determination in chickens Science 255 467-470

Erickson GF, Magoffin DA, Dyer CA and Hofeditz C (1985) The ovarian androgen producing cells: a review of structure/function relationships Endocrine Reviews 6 371-399

Gasc JM (1980) Estrogen target cells in gonads of the chicken embryo during sexual differentiation Journal of Embryology and Experimental Morphology 55 331-342

Griffiths G, Daan S and Dijkstra C (1996) Sex identification in birds using two CHD genes Proceedings of The Royal Society of London Series B 263 1251-1256

Knecht M, Darbon JM, Ranta T, Baukal A and Catt KJ (1984) Estrogens enhance the adenosine $3^{\prime}, 5^{\prime}$-monophosphate-mediated induction of folliclestimulating hormone and luteinizing hormone receptors in rat granulosa cells Endocrinology 115 41-49

Knecht M, Brodie AMH and Catt KJ (1985a) Aromatase inhibitors prevent granulosa cell differentiation: an obligatory role for estrogens in luteinizing hormone receptor expression Endocrinology 117 1156-1161

Knecht M, Tsai-Morris CH and Catt KJ (1985b) Estrogen dependence of luteinizing hormone receptor expression in cultured rat granulosa cells. Inhibition of granulosa cell development by the antiestrogens tamoxifen and keoxifene Endocrinology 117 1771-1777

Krust A, Green S, Argos P, Kumar V, Walter P, Bornert JM and Chambon P (1986) The chicken estrogen receptor sequence: homology with verbA and the human estrogen and glucocorticoid receptors EMBO Journal 5 891-897

Maxwell BL, McDonnell DP, Conneely OM, Schulz TZ, Greene GL and O'Malley BW (1987) Structural organization and regulation of the chicken estrogen receptor Molecular Endocrinology 125-35

Nakabayashi O, Nomura O, Kikuchi H, Kikuchi T and Mizuno S (1997) Estrogen synthesis and receptors during early gonadal development. In Perspectives in Avian Endocrinology pp 27-36 Eds S Harvey and RJ Etches. Society for Endocrinology, Bristol

Narbaitz R and De Robertis EM, Jr (1970) Steroid-producing cells in chick intersexual gonads General and Comparative Endocrinology 14 164-169

Perrin FMR, Stacey S, Burgess AMC and Mittwoch U (1995) A quantitative investigation of gonadal feminization by diethylstilboestrol of genetically male embryos of the quail Coturnix coturnix japonica. Journal of Reproduction and Fertility $103223-226$

Richards JS, Ireland JJ, Rao MC, Bernath GA, Midgley AR and Reichert LE,
Jr (1976) Ovarian follicular development in the rat: hormone receptor regulation by estradiol, follicle stimulating hormone and luteinizing hormone Endocrinology 99 1562-1570

Romanoff AL (1960) The Avian Embryo, Structural and Functional Development 1st Edn Macmillan, New York

Smith CA, Andrews JE and Sinclair AH (1997) Gonadal sex differentiation in chicken embryos: expression of estrogen receptor and aromatase genes Journal of Steroid Biochemistry and Molecular Biology 60 295-302

Sokka T, Hämäläinen T and Huhtaniemi I (1992) Functional LH receptor appears in the neonatal rat ovary after changes in the alternative splicing pattern of the LH receptor mRNA Endocrinology 130 1738-1740

Tanabe Y, Saito N and Nakamura T (1986) Ontogenetic steroidogenesis by testes, ovary, and adrenals of embryonic and postembryonic chickens (Gallus domestics) General and Comparative Endocrinology 63 456-463

Wartenberg H, Lenz E and Schweikert HU (1992) Sexual differentiation and the germ cell in sex reversed gonads after aromatase inhibition in the chicken embryo Andrologia 24 1-6

Weniger JP and Zeis A (1987) 17ß-estradiol secretion by the ovary of the hypophysectomized chick embryo General and Comparative Endocrinology 65 9-11

Weniger JP, Chouraqui J and Zeis A (1989) 17ß-estradiol secretion in normal and hypophysectomized chick embryos Reproduction Nutrition Development 29 89-93

Willier BH, Gallagher TF and Koch FC (1935) Sex-modification in the chick embryo resulting from injections of male and female hormones Proceedings of the National Academy of Sciences USA 21 625-631

Wolff E and Ginlinger A (1935) Sur la transformation des poulets mâles en intersexués par injection d'hormone femelle (folliculine) aux embryons Archives d'A natomie, Histologie et Embryologie 20 219-278

Woods JE and Erton LH (1978) The synthesis of estrogens in the gonads of the chick embryo General and Comparative Endocrinology 36 360-370

Woods JE, Mannela JA and Thommes RC (1981) The hypothalamicadenohypophyseal-gonadal axes in the developing chick embryo General and Comparative Endocrinology 45 66-73

Woods JE, Scane CG, Seeley M, Cozzi P, Onyeise F and Thommes RC (1989) Plasma LH and gonadal LH-binding cells in normal and surgically decapitated chick embryos General and Comparative Endocrinology 74 1-13

Yoshida K, Shimada K and Saito N (1996) Expression of P45017a hydroxylase and P450aromatase genes in the chicken gonad before and after sexual differentiation General and Comparative Endocrinology 102 233-240

Zhang FP, Hämäläinen T, Kaipia A, Pakarinen P and Huhtaniemi I (1994) Ontogeny of luteinizing hormone receptor gene expression in the rat testis Endocrinology 134 2206-2213 